\title{
Analysis of Intra- City Public Transport System of Ojuelegba Park, Lagos State, Nigeria
}

\author{
Atoyebi, A.01 \\ Gbadamosi, T.K² \\ Nwokoro, I.I.C 3 \\ Omole, F.K $\mathbf{4}^{*}$ \\ 1,3 Department of Urban and Regional Planning, University of Lagos, Nigeria \\ 2 Department of Transport Management Technology, Federal University of Technology, Akure, Nigeria \\ ${ }^{4}$ Department of Urban and Regional Planning, Federal University of Technology, Akure, Nigeria \\ ${ }^{*}$ Correspondent Author
}

\section{Doi:10.5901/mjss.2015.v6n2s1p624}

\begin{abstract}
Urbanization coupled with the increase in economic activities among other factors is responsible for the increase transport demand. This study exams the use and the service efficiency of intra-urban bus services at 'Ojuelegba', a popular district in Lagos, Nigeria. Methods of investigation include; physical observation and field inventory of the buses and facilities at the park, oral interviews of stakeholders and administration of questionnaires among others. Both descriptive and inferential analyses were used for data analysis. Findings show that age groups between 31-50 years were dominant in the patronage and uses of public transport. The highest number of trips made by drivers per day was four; that was because of traffic delay in virtually on the roads. The major purpose for trip making was for business. The National Union of Road Transport Workers (NURTW) unjustly exhorts money from bus operators and lastly, long waiting time by passengers for buses to load at the park was another problem identified. Recommendations include; (i) an appeal for reduction of bus ticket fee to reduce cost of travels, (ii) the need for test of busses and test for road worthiness of busses periodically at the park, and lastly; and (iii) provision for conveniences at the park to make the park more functional and environmental friendly.
\end{abstract}

Keywords: Service efficiency, intra-urban, trip frequency, Lagos, Nigeria.

\section{Introduction}

The level of public transport provision in the third world is very low. The supply of Public transport can no longer cope with the demand. This is due to the rapid urbanization and the increasing economic activities in developing part of the world which make it difficult for the transportation needs of the people to be fully satisfied. In studying the roles and adverse effects of transportation in cities, many researchers like Vuchic, 2005; Sperling, 1995; and others submit that transport is a catalytic force and agent responsible for both economic growth and decline, especially where economic resources and conditions as well as human endeavor are insufficient. In this vein, efficient transportation system should be seen as a factor that unite the entire economy and facilitates development (Olorunfemi and Basorun, 2013; Kwakye et al, 1994) noted that a well functioning transport system helps to maximize the economic growth and progress of cities. Public transportation system provides the most efficient means of moving large number of people especially in high populated urban centres. In addition to the well being of its users, public transport plays a vital role in the productivity of cities which in turns has a direct bearing on the national economies (World Bank, 2001; Lyndon and Todd, 2006).

According to the World Bank Report (1975); transportation is the movement of people and goods from one location to another (Okoko, 2006). Mode of transport includes air, road, rail, water, cable, pipeline and space. Terminals in transport may be used for both interchange of passengers and cargo and for maintenance. Vehicles travelling through this terminal may include automobiles, bicycles, buses, trains, truck, people, helicopters and aircraft operations. Public transportation, by definition, connotes the act or the means of conveying large number of people 'en masse' as opposed to conveyance in individual vehicles, carrying very few people at a time. In other words, public transport or mass transit is a system in which a greater number of people are moved at a time along principal corridors (Ogbazi, 1992; Nwachukwu, 2005). Public transport or mass transit comprises mainly of the rail system (light rail, tram ways and monorails), bus system and where possible water transportation (Nwachukwu, 2005). There are $40.0 \%$ fewer buses per head of 
population in the third world and the average number of buses operated per 100,000 populations is $65.0 \%$, whereas in the United Kingdom, the figure is $90.0 \%$. In Kuala Lumpur, there is only one motorcycle to 15.4 persons and one car per 11.17. In low-income households in Jamaica, Hearty (1980) found only one car per 49 persons while in Beijing, private car ownership is almost non-existent and $45.0 \%$ of all journeys are made by bicycle (Lam, 1992). In West African cities; generally, car ownership levels is very low, an average of $5-15$ per 1000 population. This compares poorly with cities of the developed countries with an average of $20-40$ cars per 100 inhabitants (White, 1990). In the developed environment where similar mobility problems exist or where there are some signs of crisis, majority of the populace rely heavily on various forms of public transport for their movement (Nash, 1997).

The density of the Lagos population, the inadequate level of road space, the land-use characteristics and the absence of a mass transit system, combined with poorly executed development plans and encroachments on road space, have given rise to numerous transportation problems in the Lagos metropolis (Abbas, 2007). These include increasing traffic congestion, worsen state of disrepair of roads, deteriorating comfort of road-based public transport, sky-rocketing transport fares, rising levels of road accidents and increasing rates of traffic-related emission and atmospheric pollution as well as the growing menace of okada (motorcycle) transporters and area boys. Traffic congestion is however exacerbated by the operation of danfos and molues. There is an increasing need for road-based public transport to serve the ever-growing population and this gap has been filled by the informal private sector. The number of mini-buses has increased tremendously in the last few years to the extent that there are now around 75,000 mini-buses registered in Lagos. Unfortunately these vehicles now constitute the greater cause of congestion on Lagos roads (LAMATA, 2008).

The public transportation challenges that are directly associated with the sprawling urban growth of Lagos are further aggravated by its status as the hub of the nation's economic, commercial and industrial activities. Most of Nigeria's manufacturing outfits are concentrated in Lagos and $45.0 \%$ of the nation's skilled manpower is resident in the city (LAMATA 2008). In addition to this, the city remains Nigeria's gateway, housing the nation's principal commercial sea and airports. The transportation inadequacies places a greater burden on the poor in urban Lagos as expenditure on transport is about $20.0 \%$ of the household budget, second only to expenditure on food (LAMATA, 2008). Advantage of public transport are many; amongst them are its effective use of space, more energy efficient, emit less airborne pollutants, minimize the amount of land used for transport purposes including parking and generally result in better physical environment in urban areas (Ume, 1991; Somuyiwa, 2008). It has also proved to be an effective tool in combating congestion. Because of these numerous advantages that public transport offers, governments in the third world countries are now becoming aware that for developing countries to be more productive, improving public transport should be one of the most pressing items on their agenda. Transportation is a requirement for every nation regardless of its industrial capacity, population size or technological development. The current state of Nigerian transportation is a product of fifty years of colonial rule and the mismanagement of forty years of relative neglect under civilian rule. The thrust of this research however, is to examine the service efficiency of intra-urban public transport system with a view to determining its impact on the trip frequency in metropolitan area of Lagos State.

\section{An Overview of the Study Area}

The study was carried out in Lagos Metropolis (Figure 2), located in the South-western part of Nigeria. It is the largest city in Nigeria with approximately 16 million people covering $37.0 \%$ of the land area of Lagos State and accommodates about $85.0 \%$ of the state population. The projected average population density of the built-up area of Lagos metropolis is about 20,000 people per square kilometer. By 2025, Lagos will become the third largest global city with an estimated population of 24 million people. Lagos has the highest vehicular density in Nigeria, estimated at 222 vehicles per $\mathrm{km}$ as against the national average of 11vehicles per km (LAMATA, 2008). Ojuelegba, (see figure 3) the case study for this research, is one of the key transport nodes of Lagos transport network that connects the city's mainland districts with Lagos Island, Victoria Island and the Lekki Peninsula to the south-east, the busy International Airport, Apapa to the south and the International Airport to the north, via the ubiquitous yellow bus transit. It is also a vital connection point for travel within the mainland area itself, allowing 'Lagosians' to commute between the three surrounding districts of Yaba, Mushin and Surulere. 


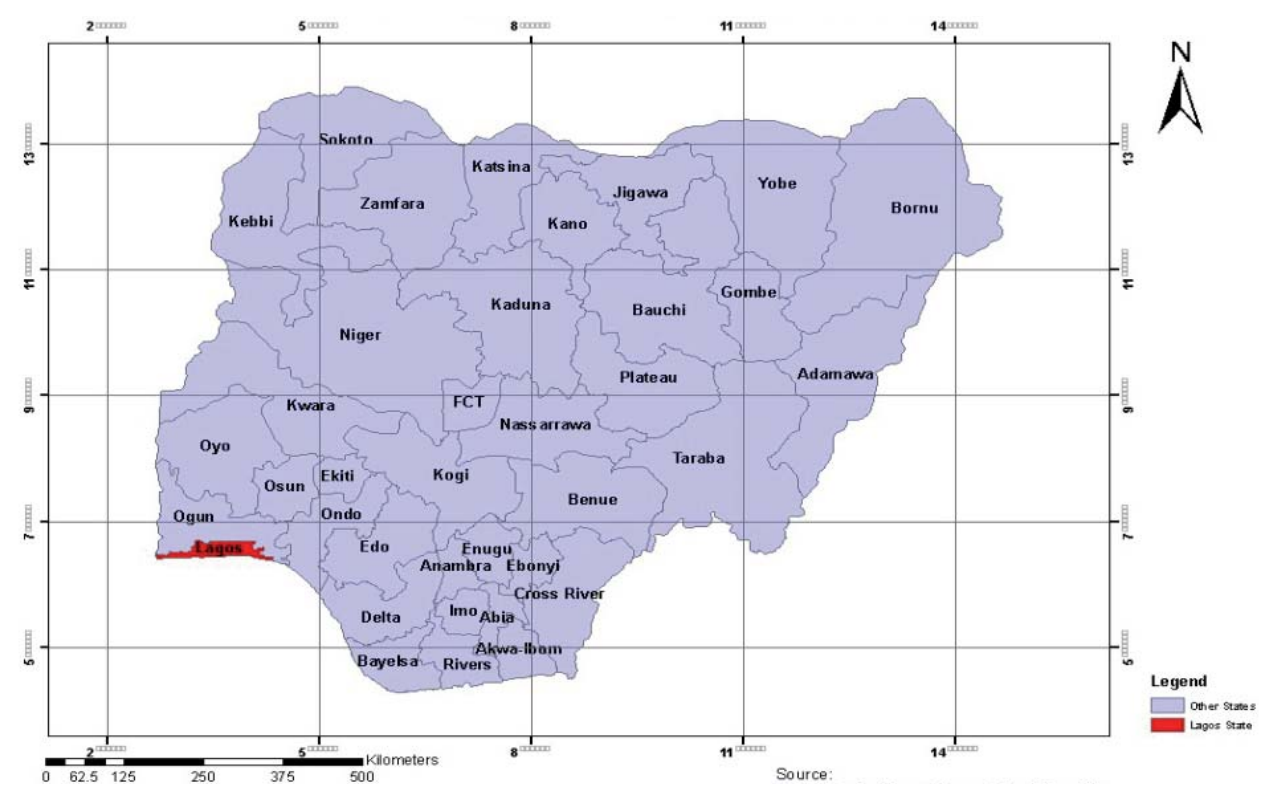

Figure 1: Lagos State in the National Setting

Source: Lagos State Ministry of Physical Planning

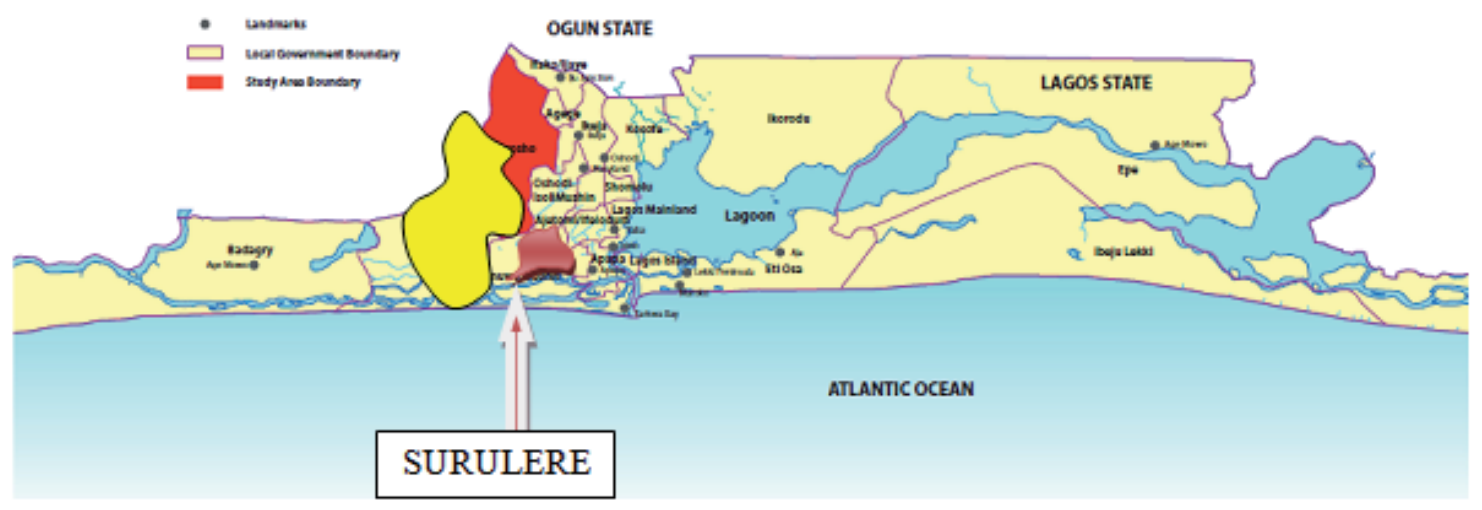

Figure 2: Map of Lagos State showing Surulere LGA

Source: Lagos State Ministry of Physical Planning, Lagos

Ojuelegba which literarily means "the eyes of the cane owner" or "a tribal marked face" as some choose to interpret it; actually has a different deep-rooted meaning. The name Ojuelegba originated from the idol called Elegba, whose shrine was located at a spot called Oju. The name Ojuelegba emanated from the description of that spot which is Ojuelegba, meaning the shrine of Elegba. Ojuelegba is a popular area in Lagos bordered by other towns like Mushin, Yaba, and Surulere. It is popularly known for its rowdy setting, tensely populated with 'Yahoo lads' popularly called 'area boys'. Street workers dot the neighbourhoods and the surroundings at night thereby making the area to have evolved over time to a commercial centre in Lagos, with commercial buses combing the way through it. A complete account cannot be given without a documentation of the hustling and bustling that takes place at the popular Ojuelegba environment. The noise is something a first-timer to the neighbourhood can never miss. Those with countless experience of Lagos town even say the area boys and the noisy environment constitute a nuisance. 


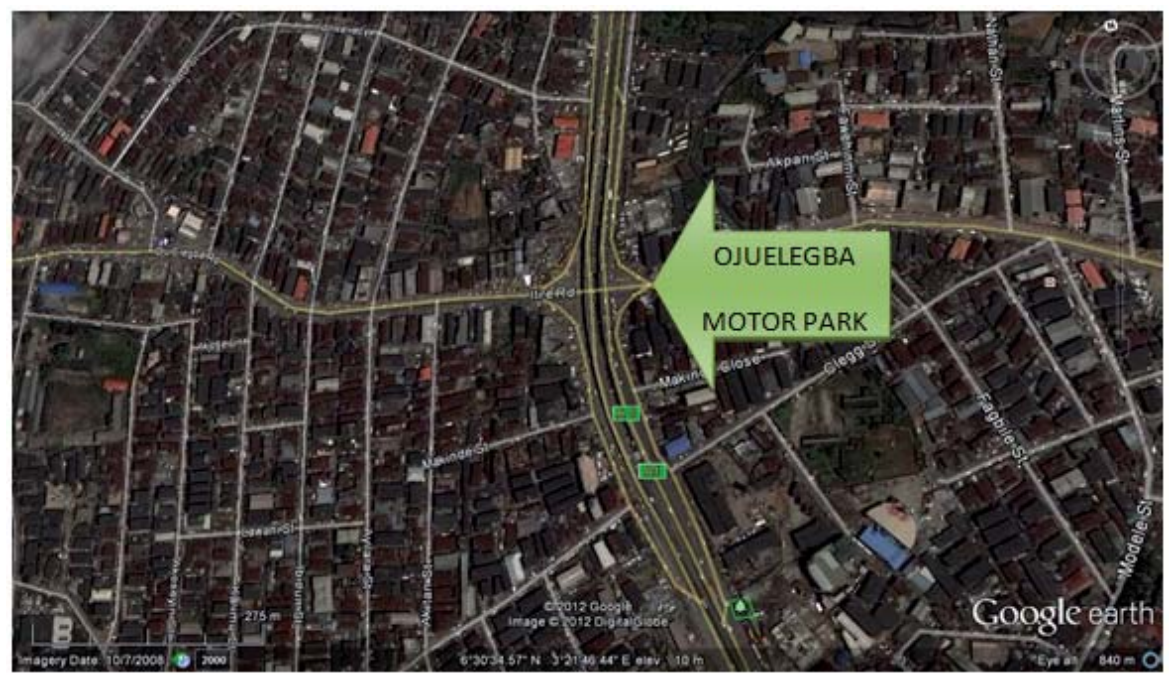

Figure 3: Map showing Ojuelegba Area - The case study

Source: Google Earth, 2012

\section{Conceptual Framework}

Five basic theoretical models proved anchor for this work. These are explained below in 3.1 to 3.5 .

\subsection{Trip Generation Model}

Trip Generation is the first step in the conventional four-step transportation forecasting process widely used for forecasting travel demands followed by Destination Choice, Mode Choice, and Route Choice. It predicts the number of trips originating in or destined for a particular traffic analysis zone. Every trip has two ends - trips origin zone and trips destine zone. Generally, land use is divided into two broad categories - residential and non-residential land uses. For residential land use, trip generation is a function of social and economic attributes of households which are often measured as housing unit variables. At the level of the traffic analysis zone, land uses often produce or attract trips, where by assumption trips are produced by households and attracted to non-household sectors. Production and attractions differ from origins and destinations. Trips are produced by households even when they are returning home; that is, when the household is in destination (Ume, 1991; TPH, 1992). In these two categories of trip generation models and trip production models estimate the number of home-based trips to and from zones where trip makers reside; while trip attraction models estimate the number of home-based trips to and from each zone at the non-home end of the trip. According to Barnes and Davis (2000), different production and attraction models are used to measure each trip purpose.

\subsection{Trip Distribution Model}

Trip distribution (or destination choice or zonal interchange analysis) is the second component after trip generation, (but before mode choice and route assignment) in the traditional four-step transportation forecasting model. The trip distribution stage takes actual trips from the trip generation model and matches them with trips attracted to destination zones (Oryani and Harris, 1996). In this sense, the distribution phase stimulates the distribution of predicted trips for origin zones to destinations. Often the distribution mechanism employed is the gravity model. Here, the number of trips made between an origin and destination is governed to be proportional to some measure of the destination zone's 'mass' (e.g. the volume of activity opportunities there) and inversely proportional to some measure of travel impedance.

\subsection{Modal split}

The modal split sub-model is concerned with estimating what proportion of trips is made by each defined mode of travel from an origin to a destination zone. In mathematical terms, this is most commonly expressed as a multinomial logit model. The logit model represents the mode choice as a function of the disutility or cost of using one mode of travel (e.g. 
private automobile) over another like public transit (Oryani and Harris, 1996). See the graphic illustration below:

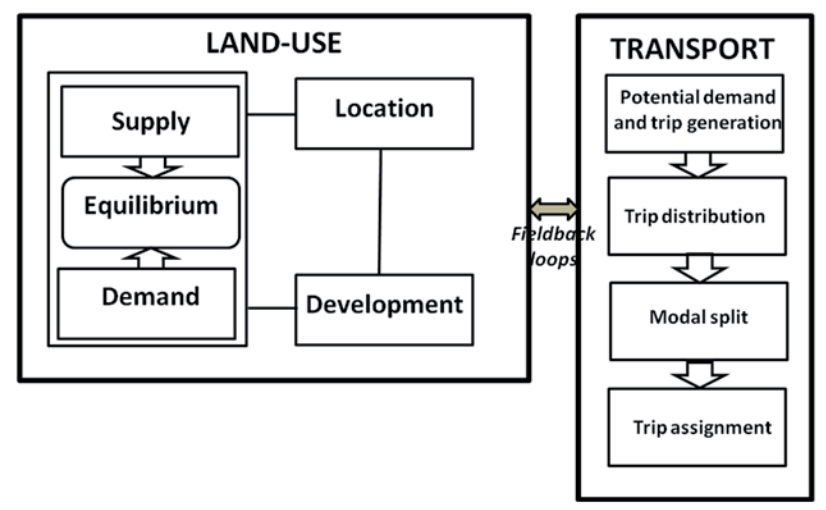

Figure 4: The general structure of a land-use-transportation model

Source: Oryani and Harris, 1996

\subsection{The Gravity Model}

The gravity model is much like Newton's theory of gravity. It assumes that the trips produced at an origin and attracted to a destination are directly proportional to the total trip productions at the origin and the total attractions at the destination. The calibrating term or "friction factor" (F) represents the reluctance or impedance of persons to make trips of various duration or distances. The general friction factor indicates that as travel times increase, travelers are increasingly less likely to make trips of such lengths. Calibration of the gravity model involves adjusting the friction factor. The gravity model illustrates the macroscopic relationships between places (say homes and workplaces). It has long been posited that the interaction between two locations declines with increasing distance, time, and cost between them, but is positively associated with the amount of activity at each location. In analogy with physics, Reilly (1929) formulated Reilly's law of retail gravitation, and Stewart (1948) formulated definitions of demographic gravitation, force, energy, and potential, now called accessibility (Hansen, 1959). An important consideration in developing the gravity model is "balancing" productions and attractions. Balancing means that the total productions and attractions for a study area are equal. The relationship between the origin and destination will therefore be determined by the same number of factors which are time, cost and the distance.

\subsection{Spatial Interaction Model}

Spatial interaction is a dynamic flow process from one location to another. It is a general concept that may refer to the movement of human beings such as intra-urban commuters or intercontinental migrants but may also refer to traffic in goods such as raw materials or to flows of intangibles such as information. In Ullman's conception, there were three bases for spatial interaction which include Complementarity, transferability, and intervening opportunity. According to him, Complementarity refers to the presence of a demand or deficit at one location and a supply or surplus at another without which there is no economic rationale for any movement. In this regard, a workplace such as factory or office tower is an example of a place with a demand for labor while a residential neighborhood provides a source of workers. A sawmill requires logs while a forest provides them. To adapt this metaphor from physics perspective, Complementarity is like a potential gradient with goods and people flowing from a higher energy state where they are in surplus to a lower energy state, where they are in deficit. The complementary surplus-deficit relationship is commodity-specific, and if the deficit is precisely specified, the direction and distance of movement will depend on the location where there is a surplus of just that kind of good. Complementary relationships therefore serve as an impetus for interaction between distant regions and within regions to small convenience stores over a distance of less than a mile or two.

Transferability, as the second basis for spatial interaction refers to the cost of overcoming distance measured in real economic terms of either time or travel cost. The cost of overcoming distance is known as the friction of distance. If the friction of distance is too great, interaction will not occur in spite of a complementary supply-demand relationship. Friction of distance depends on prevailing transportation technology and the price of energy. In general, the friction of distance has decreased over time which is the prime factor in globalization and the emergence of megacities. Daily commuter flows, for example, are always subject to a travel time constraint with two hours being a typical maximum for 
the one-way daily journey to work. High-value, low-weight goods such as jewelry are imminently transferable and exported on a global scale while heavy, low-value goods such as concrete blocks are usually used very close to where they are produced.

Intervening opportunity as the third basis for interaction is considered as the reason for a lack of interaction between two complementary locations. Complementarity will only generate a flow if there is no intervening or closer alternative location. The flow of goods that would otherwise occur between two complementary locations may be diverted to a third location standing as closer complementary alternative with a cheaper overall cost of transportation. However, Ullman noted that the trade diverting effect of an intervening opportunity could eventually facilitate interaction between more distant complementary locations. In his example, the nearest (intervening) source of logs would justify construction of a short logging railway from the mill to the forest resource and when it was harvested, the railway would be extended to the next intervening opportunity and so on until it ultimately reached a more distant complementary location. Flows to the more distant complementary location might never have been established had the transportation infrastructure not been constructed in a series of incremental extensions to a series of intervening opportunities.

\section{The Research Methodology}

Data were obtained from both primary and secondary sources via questionnaire administration, physical observation, personal contacts and oral interview of appropriates stakeholders. Two set of questionnaire was administered for analysis of intra-urban public transport operation of bus services in Ojuelegba Motor Park, one for bus operator while the second was directed to the passengers. Sample size of commuters was taken based on average passenger capacity on different routes from Ojuelegba being the origin. The distribution is shown in Table 1 while Table 2 expresses the variable used to assess the level of functionality and inventory of the Ojuelegba motor park.

Table 1: Average Number of Buses Going to Different Route

\begin{tabular}{ccccc}
\hline Origin & Destination & No. of buses & Average passenger capacity @18 prs/bus & 10\% Sample Size taken \\
\hline Ojuelegba & Pako-Aguda & 5 & 90 & 9 \\
Ojuelegba & Masha-kilo & 7 & 126 & 12.6 \\
Ojuelegba & CMS & 6 & 108 & 10.8 \\
Ojuelegba & Apapa-wharf & 8 & 144 & 14.4 \\
Ojuelegba & Ikeja/Opebi & 10 & 180 & 18 \\
Ojuelegba & Mushin & 8 & 144 & 14.4 \\
Ojuelegba & Ogba Agege & 5 & 90 & 9 \\
Ojuelegba & Yaba & 8 & 144 & 14.4 \\
Ojuelegba & Lawanson/ljesha & 7 & 126 & 12.6 \\
Ojuelegba & Oshodi & 6 & 108 & 10.8 \\
Ojuelegba & ljora/Badia & 6 & 108 & 10.8 \\
Ojuelegba & Ajegunle & 5 & 90 & 9 \\
Ojuelegba & Iyana-Ipaja & 5 & 90 & 9 \\
Ojuelegba & Orile/Bode Thomas & 7 & 126 & 12.6 \\
Ojuelegba & Ketu-ojota & 10 & 180 & 18 \\
Total & & 103 & 1854 & 185.4 \\
\hline
\end{tabular}

Source: Field Survey, 2012

Table 2: Bus Operators' Evaluation Table

\begin{tabular}{|c|c|c|c|c|c|}
\hline Criteria & Excellent & Very Good & Good & Fair & Poor \\
\hline Cleanliness & & & & & \\
\hline Safety & & & & & \\
\hline Availability & & & & & \\
\hline Dependability & & & & & \\
\hline Functionality & & & & & \\
\hline
\end{tabular}

Source: Field Survey, 2012 
Data collected were analyzed using both descriptive and inferential statistical analysis. The descriptive analysis entailed the use of frequency tables in order to get a general understanding of the operations, travel characteristics and challenges of respondents. The inferential analysis entailed the use of Stepwise Multiple Regression analysis in order to inquire into the contributions of the passengers' travels characteristics to the travel frequency.

\section{Research Findings and Discussion}

As pointed out in the methodology, two set of questionnaire (Bus Operator and Passenger) was administered for analysis of intra - urban public transport operation of bus services in Ojuelegba Motor Park. The survey conducted on the age group of drivers reveals that $42.9 \%$ of the sampled respondents were between $16-30$ years while the remaining $57.1 \%$ claimed to be between the age group of 31-50 years. This analysis shows that the work is for adult who are known to be energetic people. Hence, people below 15 years and those above 50 years are not involved in bus operation business in the study area. About $28.6 \%$ of the respondents were single, while $66.7 \%$ are married; only $4.8 \%$ is divorced. This analysis shows that majority of the bus operators are married while the widowed and others have no representation. This analysis can be attributed to the age of the sampled respondents.

\subsection{Monthly Income}

Survey conducted on average monthly income shows that about $33.3 \%$ of the respondents make between N10,001 $\mathrm{N} 20,000$ monthly, 52.3\% make between $\mathrm{N} 20,001$ - N40,000 in a month while the remaining $14.4 \%$ claimed to make between $\mathrm{N} 40,000$ - N60,000 monthly. Further analysis of estimated monthly income of the drivers revealed that no one make below N10, 000 and above N 60,000 monthly in the study area. This is shown in Table 3 below.

Table 3: Average Monthly income of the Respondent

\begin{tabular}{lll}
\hline Monthly Income & Frequency & Percent (\%) \\
\hline N10,000 \& below & - & - \\
N10,001 - N20,000 & 7 & 33.3 \\
N20,001 - N40,000 & 11 & 52.3 \\
N40,001 - N60,000 & 3 & 14.4 \\
Above N 60,000 & - & - \\
Total & 21 & 100 \\
\hline
\end{tabular}

Source: Field Survey, 2012 Naira N is the Nigeria currency. 165 Naira= 1US Dollar as at the time of this survey

\subsection{Income level and Trip frequency}

The figure below shows the relationship between income level and trip frequency of bus operators, which implies that the higher the trip frequency per day the higher the average monthly income of bus operators in the study area.

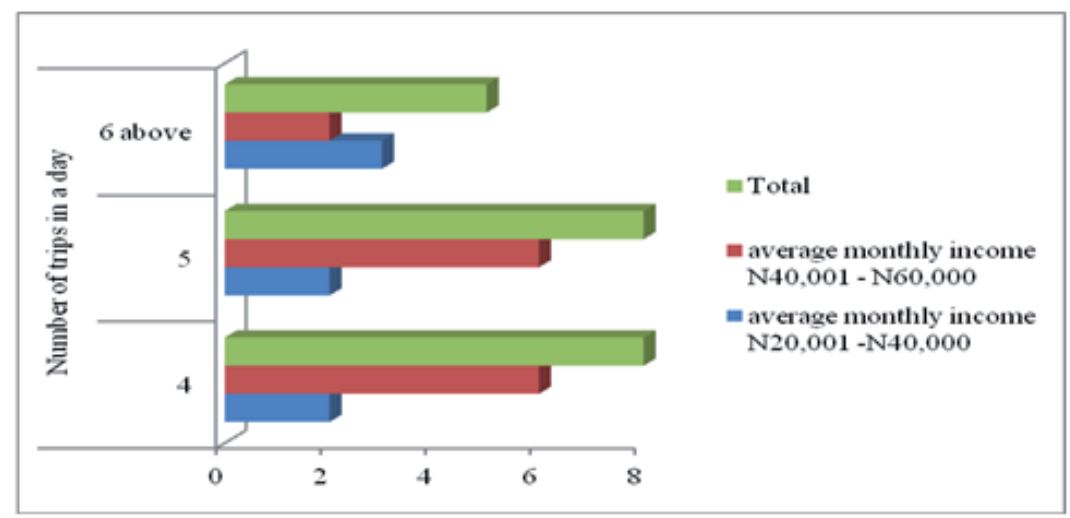

Figure 5: Relationship between Income and Trip Frequency

Source: Field Survey, 2012 


\subsection{Travel Routes Analysis and Daily Trip Frequency}

Table 4 below shows the detail analysis of different travel routes plied by drivers in terms of distance cover, delay points, average time spent and the cost of travel on each route.

Table 4: Travel Routes Analysis

\begin{tabular}{ccccc}
\hline Travel Route & Distance Travel & Travel Delay point & $\begin{array}{c}\text { Average Travel } \\
\text { Time (Mins) }\end{array}$ & $\begin{array}{c}\text { Travel Cost in } \\
\text { Naira }\end{array}$ \\
\hline Itire - ljesha & $1500 \mathrm{~m}$ & Itire road & 20 & 70 \\
Ketu-Ojota & Above $2000 \mathrm{~m}$ & Ikorodu road & 30 & 150 \\
Pako-Aguda & $1500 \mathrm{~m}$ & Ogunlana Drive & 35 & 100 \\
Apapa-Wharf & Above $2000 \mathrm{~m}$ & Barracks \& Airways & 35 & 100 \\
Lawanson & $1000 \mathrm{~m}$ & Itire road & 15 & 50 \\
ljora-Badia & $2000 \mathrm{~m}$ & Brewery \& 7Up & 25 & 70 \\
Ajegunle & Above $2000 \mathrm{~m}$ & Boundary to Marina bridge & 35 & 100 \\
Mushin & $1000 \mathrm{~m}$ & Agege motor road, Isolo Road Interchange. & 20 & 50 \\
Ikeja & Above $2000 \mathrm{~m}$ & Ikorodu road, Mobolaji Bank Anthony Way & 40 & 150 \\
Opebi Allen/lkeja & Above $2000 \mathrm{~m}$ & Maryland, Mobolaji Bank Anthony Way & 40 & 200 \\
Orile -Iganmu & Above $2000 \mathrm{~m}$ & Bode Thomas Road \& Adeniran Ogunsanya & 40 & 70 \\
Masha Kilo & $1000 \mathrm{~m}$ & Stadium \& Ogosco & 20 & 50 \\
Ogba/Agege & Above $2000 \mathrm{~m}$ & Ikeja under bridge, Oba Akran - Guinness & 50 & 200 \\
Yaba & $500 \mathrm{~m}$ & Ojuelegba road & 5 & 30 \\
CMS/Obalende & $1500 \mathrm{~m}$ & & 15 & 100 \\
\hline
\end{tabular}

Source: Field Survey, 2012

Findings show that one-third of the drivers, 33.3\% make 4 trips daily, 19\% were able to make above 6 trips daily while about $47.6 \%$ claimed that they make 5 trips daily based on their route. Further discussion with the drivers disclosed that based on the number of buses in the study area; no driver/operator can make less than 4 trips daily all things being equal. Basically, the reason why some drivers make 5 trips and others make lesser trips per day is as a result of distance they travel and traffic congestion along their travel route. This analysis further illustrates the number of vehicles operating daily based on different routes in the study area. About $14.3 \%$ respondents suggests that there are $6-10$ vehicles operates daily, $23.8 \%$ claimed $11-15$ vehicle operates daily while $61.9 \%$ averred that there are over 16 vehicles operating daily in the study area based on the route they travel. Beside the problem of traffic congestion that constitutes unnecessary delay to motorists; other important problem is in the area of union extortion. Bus operators revealed that the major challenge they face at the park is the excessive extortion from National Union of Road Transport Workers, which they claimed that if the union can reduce their fee, it will enable them to maintain their buses well and render better services. Also, some of the operators complained of paying double fees (that is, at points of origin and destination).

Further analysis on Daily fueling cost and frequency revealed the average cost incurred by drivers in fueling their buses daily. Respondents plying Pako-Aguda, Lawanson, ljora-Badia, Mushin and Masha Kilo stated that they spend between N2, 500 - N3, 000 daily, those plying Itire/ijesha, Apapa wharf, Ajegunle, Mushin and Orile-Iganmu/Bode Thomas claimed to spend between N3, 000 - N3,500 daily while those plying Ketu - Ojota, Ikeja/ Opebi Allen and Ogba/Agege stated that they spend over N3,500 daily on fuel. It can be deduced from this analysis that the longer the distance traveled, the higher the cost of fueling. Also, all the respondents claimed they rarely have fueling difficulties apart from general fuel scarcity. The survey also reveals $57.1 \%$ of the respondents fuelling their vehicles twice daily while $42.9 \%$ claimed only once in a day.

\subsection{Travel Time, Distances Travel and purpose of Travel.}

Figure 6 below shows that the passengers traveled most in the area. However, About $35.7 \%$ of the passengers interviewed travel early in the morning, $14.1 \%$ travel between $10 \mathrm{am}$ and 12 noon, $6.5 \%$ traveled during off peak period, between 12 noon and 2pm; $13 \%$ traveled between $2 \mathrm{pm}$ and $4 \mathrm{pm}$ while $30.8 \%$ traveled during evening peak period. Further discussion with the passengers reveals their travel distances. About $7 \%$ of the passengers travel less than $500 \mathrm{~m}$, $4.9 \%$ travel between $500 \mathrm{~m}$ and $1000 \mathrm{~m}, 27 \%$ travel between $1000 \mathrm{~m}-1500 \mathrm{~m}$ while majority $(61.1 \%)$ of the passengers travel more than $2000 \mathrm{~m}$ away from the study area. Thus, most of them that travel more than $2000 \mathrm{~m}$ leave very early in 
order to get bus to their destination on time. The reason for this is not farfetched as most of the passengers stated that they take 2 to 3 buses before getting to their destination point.

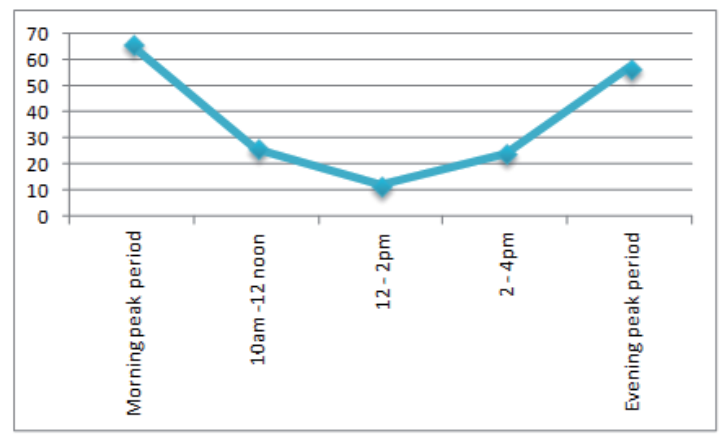

Figure 6: Passengers Travel time

Source: Author's Field survey, 2012

Further interview with the passengers revealed that $24 \%$ of the passengers travel for business purpose, $16.8 \%$ for educational purpose, $18.4 \%$ travel for pleasure, while $18.4 \%$ travel to visit and $22.4 \%$ travel to work for their daily bread. In ranking the travel purpose in order of priority; $49.7 \%$ of the passengers claimed that the trip they make is compulsory, which is either for business or educational purpose. About $27.6 \%$ claimed that their trips are necessary, usually for pleasure while $22.7 \%$ stated that their trips are optional.

\subsection{Challenges Faced by the passengers at the motor park}

Findings from the survey revealed that majority of the passengers waits for a long time before they get buses at peak periods (Rush hour) where there are more passengers waiting for bus and there are few buses to carry them. However, the challenges the passengers faced at the Ojuelegba Motor park include inadequacy of buses for efficient service delivery, prolong waiting time, unavailability of bus stops, overcrowding, intolerable attitude of drivers and conductors, bad odour from conductors in the act of collecting transport fare from passengers, lack of conveniences for passengers to ease themselves when they are been pressed at the Motor park, and unexpected bus breakdown as a result of negligence of drivers.

\subsection{Vehicular Operations and Traffic Volumetric Count in the Study Area}

Generally, this study revealed that the level of vehicular operational service in the study area has significant relationship with how often the passengers go to the park, the travel time, purpose or priority of travelling passengers, waiting time and travel distance. Hence, the regression equation:

$Y=a+b_{1} X_{1}+b_{2} X_{2}+b_{3} X_{3}+b_{4} X_{4}$ .bnXn + e gives its value as:

$Y=-1.314+0.780+0.426+0.218+0.207$; where

$Y$ is the dependent variable, i.e. how often the passengers go to the park (measured on daily basis, once a week, twice a week or occasional travel); $\mathbf{a}=$ constant. The $\mathrm{X}_{1}, \mathrm{X}_{2} \ldots . . \mathrm{X}_{\mathrm{n}}$ are independent variables which includes travel time measure in minutes or hours; distance of travels measured in meters; passengers' waiting time for bus measured in minutes; purpose of travels which may either be for business, education, pleasure, visit or work as well as the priority of travel measure by compulsory, necessary or optional. The $b_{1}, b_{2} \ldots \ldots \ldots b_{n}$ are the coefficient of independent variables while $\mathrm{c}$ is random error term measuring the deviation of the observed trips $(Y)$. The model summary is shown in Tables 5 and 6 below.

Table 5: Model summary of how often do you come to the park

\begin{tabular}{cccc}
\hline Model & $\mathrm{R}$ & R Square & Std. Error of the Estimate \\
\hline 1 & $.661(\mathrm{a})$ & .437 & 1.06707 \\
2 & $.707(\mathrm{~b})$ & .499 & 1.00907 \\
3 & $.725(\mathrm{c})$ & .526 & .98421 \\
4 & $.736(\mathrm{~d})$ & .541 & .97119 \\
\hline
\end{tabular}

Source: Computer Print-out 
Table 6: Coefficient Summary

\begin{tabular}{ccccccc}
\hline \multirow{2}{*}{ Model } & \multicolumn{2}{c}{ Un-standardized Coefficients } & Standardized Coefficients & T & Sig. \\
& $\mathrm{B}$ & Std. Error & Beta & $\mathrm{B}$ & Std. Error \\
\hline (Constant) & -1.314 & .345 & & -3.805 & .000 \\
Priority of traveling & .780 & .146 & .455 & 5.353 & .000 \\
Distance travel & .426 & .085 & .259 & 5.005 & .000 \\
How often do you wait to pick a bus from the park & .218 & .074 & .149 & 2.965 & .003 \\
What is your travel time & .207 & .083 & .211 & 2.486 & .014 \\
\hline
\end{tabular}

Source: Computer Print-out

The Coefficient and Model Tables showed above revealed the most significant variables that could determine the impact of bus service on passenger trip frequency in the study area. These variables are travel time, travel distance, passengers' wait time, priority of traveling and travel purpose. The other significant variables had been considered in the excluded variables by the step wise multiple regressions. The travel and waiting time of passenger in most cases is as a result of efficiency and operation of buses services as the inferential model revealed that the temporal travel time, waiting time, travel distance, priority and purpose of travel of the respondents to be $\mathrm{R}^{2}=54.1 \%$.

In the model summary table, it can be deduced that different factors contribute to the frequency at which people go to the study area to board bus. Regression model summary in table 5 indicated the value of $\mathrm{R}^{2}$ for combined independent variable to be 0.541 (i.e. $54.1 \%$ ). Priority of travel had the highest contribution to trip frequency when $\mathrm{R}^{2}$ is $0.437(43.7 \%)$, trip frequency increase to $0.499(49.9 \%)$ when travel distance was included in the model summary, also $\mathrm{R}^{2}$ increase to $52.6 \%$ and $54.1 \%$ respectively when waiting time and travel time was added to the summary.

Traffic volumetric count was conducted to determine the level of traffic volume in the study area to various route. There are four major travel routes that connect ojuelegba (the study area) to other locations; and the traffic count was taken from this four routes, which are Western Avenue to Barracks, Barracks to Western Avenue, Yaba to Lawanson, Lawanson to Yaba. The exercise run through the period of three days which include Monday, Wednesday and Saturday with the time duration of $7 \mathrm{am}-7 \mathrm{pm}$.

\section{Summary of Findings and Policy Recommendations}

Findings from the study revealed that age group $31-50$ is more involved in bus driving activities, which shows that the work is for adult and energetic people. The drivers analysis revealed that no one make below N10, 000 and above $\mathrm{N}$ 60,000 monthly in the study area. The drivers disclosed that based on the number of buses in the study area no driver/operator can make less than 4 trips daily all things being equal. The analysis reveals causes of travel delay; nearly all the routes encounter traffic problem. It was clearly stated that the volume of traffic from different delay point varies with impact on travel time, the number of trips a bus operator will make in a day and also the cost of travel the passengers will pay. The study also reveals that more passengers travel more than $2000 \mathrm{~m}$ away from the study area and most of them travel for business purpose. Passengers waiting time is the time a passenger arrives at the motor park and the time that he/she eventually boarded and departs. It was also revealed that the major challenge the bus operators face at the park is the excessive extortion by the National Union of Road Transport Workers. Most of the operators complained that they pay double fee in the sense that they pay loading and ticket fee at Ojuelegba Motor Park (point of origin) and also pay another fee at the park of destination. Passengers equally complained about the long time they wait before they get buses at peak periods. To this end, the following recommendations are proffer to allay the identified problems.

The paper suggests a drastic reduction in ticket fees paid by the drivers so as to reduce cost of travels for passengers and help operators to save to maintain their buses and render better services. There is need for the National Union of Road Transport Workers (NURTW) and the Road Transport Employers' Association of Nigeria (RTEAN) to stop allowing bus that are not registered with the park from loading, if this is done, it will reduce delay and reduce passengers waiting time in the motor park. The operators and passengers suggest the need for bus test before they start operations and that buses should be given periodic check by the Motor Park Association. This should be done before the commencement of each operation in order to avoid vehicular break down. Provision of conveniences at the park should be considered as priority so as to keep the surroundings clean, hygienic and free of stagnant urine. Government in agreement with the unions should reduce the amount paid by commercial drivers and conductors in registering before operating in this park; considering the fact that they are low-income earners. There is also a need for more involvement of the private participation in transport services in Lagos State. This will increase the numbers of vehicles available along 
various routes thereby reducing the waiting time of passengers at the park.

\section{References}

Abbas, 0.0 (2007). Rapid Urbanisation and Coping Strategies: The case of Lagos, Nigeria. Published Master Thesis submitted to Department of Urban Planning and Environment, Division of Urban and Regional Studies, Kungligu Tekniska Hogskolan.

Hansen, W. G. (1959). How accessibility shapes land use. Journal of the American Institute of Planners, 25(2), pp 73-76

Hearty, M.(1980). Public Transport in Jamaica, Crowthorne: Transport and Road Research Laboratory Report, No. SR 546.

Kwakye, E.A; Turner, J. and Grieco, M. (1994): A Tale of Two Cultures: Ethnicity and Cycling Behavior in Urban Ghana. Washington D.C; Transportation Research Board

Lam, H. (1992): Minibus Transport far Eastern Cities with special reference to Beijing. Unpublished PhD Thesis, University of London.

LAMATA (2008): Launching of Lagos Bus Rapid Transit; Lagos Metropolitan Transport Area Authority, Lagos Nigeria

Lyndon, H. and Todd, A.L. (2006): Evaluating New Start Transit Program Performance Comparing Rail and Bus Victoria Transport Policy Institute Canada.

Nash, C.A. (1997): Planning for Public Transport, In Flaherty, C.A. (ed.): Transport Planning and Traffic Engineering; Butterworth, Heinemann London.

Nwachukwu, A.A (2005): Assessment of Passion Satisfaction with Intra-City Public Bus Transport Service in Akure, Nigeria: Journal of Public Transportation. 17(1); 45-60

Ogbazi, J.U. (1992): Urban Transportation Planning - Principle and Practice of Urban and Regional Planning in Nigeria; Mekslink Publishers, Awka, Nigeria; pp. 64-72.

Okoko, E.E (2006): Urban Transportation Planning and Modeling. Millennium Publishers, Akure, Ondo State, Nigeria

Olorunfemi, S.O and Basorun, J.O (2013): Appraisal of Regional Mobility in Lokoja, Nigeria. Journal of Society and Communication. 2013: $420-446$

Oryani, K. and Harris, B. (1996): Enhancement of DVRPC's Travel Simulation Models Task 12: Review of Land Use Models and Recommended Model for DVRPC. Report Prepared for Delaware Valley Regional Planning Commission, URS Consultants, Inc., Philadelphia.

Reilly, W.J. (1929): Methods for the Study of Retail Relationships. University of Texas Bulletin No 2944, Nov. 1929.

Somuyiwa, A.O (2008): Impact of Transport Negative Externalities in Urban Cities of Developing Economy a Psychological Analysis. Pakistan Journal of Social Science 5(9) 918-926

Sperling, D. (1995): Future drive: electric vehicles and sustainable transportation. Island Press Washington, D.C.

Sperling, D. (1997): A new agenda - Access Fall; University of California, Berkely, U.S.A

Stewart, J.Q. (1948): Demographic Gravitation: Evidence and Application; Sociometry. XI Feb.-May 1948; pp 31-58

Transportation Planning Handbook (TPH, 1992): The Institute of Transportation Engineers Washington D. C. US pp. 108-112.

Ume, E.A. (1991): A Geographical Appraisal of the Effect of Government Bus Transit Programme in Ibadan; (Unpublished) B.Sc Project, University of Nigeria, Nsukka, Enugu Campus, Nigeria

Vuchic, V. R. (2005): Transportation for Livable Cities. New Brunswick, NJ: Center for Urban Policy Research.

White, P.R. (1990): Inadequacies of Urban Public Transport Systems. In Dimitrious, H.T. and Banjo, G.A. (eds.) Transport Planning for Third World Cities. Routledge, London.

World Bank (2001): Urban Mobility: Profitability and Financing of Urban Public Transport Microenterprises in Sub-Saharan Africa- An Overview of the Regional Study Conducted in Abidjan, Bamako, Harare and Nairobi: SSATP Working paper No. 54 African Region. 
